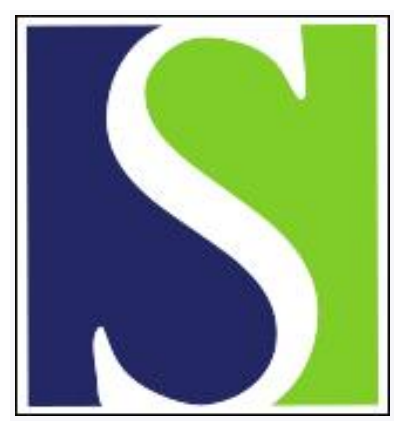

Scand J Work Environ Health 1997;23(1):31-36

https://doi.org/10.5271/sjweh.175

Issue date: Feb 1997

Blood cadmium as an indicator of dose in a long-term follow-up of workers previously exposed to cadmium

by Järup L, Persson B, Elinder C-G

Key terms: alpha ${ }_{1}$-microglobulin; beta ${ }_{2}$-microglobulin; blood cadmium; N-acetyl-beta-D-glucosaminidase; protein alfa ${ }_{1}$ -microglobulin; renal stones; tubular dysfunction

This article in PubMed: www.ncbi.nlm.nih.gov/pubmed/9098909

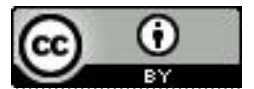




\title{
Blood cadmium as an indicator of dose in a long-term follow-up of workers previously exposed to cadmium
}

\author{
by Lars Järup, MD, ${ }^{1}$ Bodil Persson, $M D,{ }^{2}$ Carl-Gustaf Elinder, $M D^{3}$
}

\begin{abstract}
Järup L, Persson B, Elinder C-G. Blood cadmium as an indicator of dose in a long-term follow-up of workers previously exposed to cadmium. Scand J Work Environ Health 1997;23(1):31—6.

Objectives This investigation attempted to follow the tubular function of 46 workers initially examined in 1984 and heavily exposed to cadmium from 1955 to 1978 and the occurrence of renal stones among these workers. Three different markers of tubular dysfunction were also studied, and blood cadmium was evaluated as an estimate of dose after the cessation of cadmium exposure.

Methods Cadmium in blood (B-Cd) and urine (U-Cd) and the urinary excretion of $\beta_{2}$-microglobulin (U- $\beta_{2}$ microglobulin), protein $\mathrm{HC}\left(\alpha_{1}\right.$-microglobulin) and $\mathrm{N}$-Acetyl- $\beta$-D-glucosaminidase (NAG) were determined.

Results Although cadmium exposure ceased in 1978, $40 \%$ of the workers showed signs of tubular dysfunction both in 1984 and in 1993. The current B-Cd was the best dose indicator. Dose-response relationships were found for B-Cd and various tubular markers (U- $\beta_{2}$-microglobulin, protein $\mathrm{HC}$ and $\mathrm{NAG}$ ). Protein $\mathrm{HC}$ appeared to be the most sensitive, as well as an early, indicator of cadmium-induced tubular dysfunction. The levels of U-Cd had an average decrease of $48 \%$ for persons with a normal tubular function, $56 \%$ for those with slight tubular dysfunction, and $62 \%$ for workers with severe tubular damage. A history of renal stones was significantly more common for workers with high B-Cd levels.

Conclusions Cadmium-induced tubular dysfunction is irreversible and best assessed in an analysis of protein $\mathrm{HC}\left(\alpha_{1}\right.$-microglobulin) in urine. B-Cd is the best dose estimate several years after the cessation of exposure, whereas U-Cd is less suitable for dose assessment in follow-up studies of persons with persistent tubular damage.
\end{abstract}

Key terms blood cadmium, $N$-Acetyl- $\beta$-D-glucosaminidase, protein $\alpha_{1}$-microglobulin, renal stones, tubular dysfunction, $\alpha 1$-microglobulin, $\beta 2$-microglobulin.

Cadmium is a well known environmental and occupational hazard (1). The critical organs in long-term exposure are the kidneys, and the first sign of toxicity is tubular damage with an increased urinary excretion of small proteins (2). Excessive or prolonged exposure causes more severe renal effects with pronounced proteinuria, a decrease in the glomerular filtration rate, and secondary effects on the mineral and calcium metabolism $(1-3)$.

Dose-response relationships are well established for cadmium and tubular proteinuria. Different dose estimates have been used: cumulative inhaled (4) or ingested (4) amount of cadmium, current (5) or cumulative (6) blood cadmium (B-Cd) level, and urinary excretion of cadmium (4, 5, 7-9). In general, blood cadmium is regarded as an estimate of present or recent exposure, whereas urinary cadmium $(\mathrm{U}-\mathrm{Cd})$ is said to reflect the kidney or body burden $(10,11)$. Therefore, $\mathrm{U}-\mathrm{Cd}$ has been frequently used as the dose estimate.

Different indicators of early tubular dysfunction have also been suggested, for example, $\beta_{2}$-microglobulin (4), retinol binding protein (12), and, in more recent years, also protein HC [human complex-forming glycoprotein $\left(=\alpha_{1}-\right.$ microglobulin)] (13) and apolipoprotein D (14). These compounds are all small serum proteins that are filtered through the glomeruli and reabsorbed by the tubular cells. Monitoring the concentration of these proteins in urine allows the early detection of small reabsorptive defects in the tubuli $(15,16)$. Several other markers of nephrotoxicity have also been used (17), for example, N-Acetyl- $\beta$-D-glucosaminidase (NAG), an enzyme localized in lysosomes of the tubular cells. Increased activity of NAG in urine (U-NAG) has been related to persons with cadmium-induced tubular dysfunction (17).

1 Department of Environmental Health, Stockholm County Council, Stockholm, Sweden.

2 Department of Occupational and Environmental Medicine, Linköping University Hospital, Linköping, Sweden.

3 Department of Renal Medicine, Huddinge University Hospital, Huddinge, Sweden.

Reprint requests to: Dr Lars Järup, Department of Environmental Health, Box 1186, S-172 24 Sundbyberg, Sweden. 
The objective of the present study was to use 3 different markers of tubular dysfunction to evaluate B-Cd as an estimate of dose in the assessment of tubular function among workers previously exposed to cadmium.

\section{Subjects and methods}

The subjects included 46 solderers ( 44 men and 2 women) highly exposed to cadmium until 1978, when cadmium-containing solders were abandoned.

Measurements performed in 1976 revealed air concentrations ranging from 10 to $2000 \mu \mathrm{g} / \mathrm{m}^{3}$ (18). The work environment was not improved until the cadmiumcontaining solders were abandoned in 1978. Individual estimates of exposure levels were made for each worker, classifying the exposure as low, medium, or high. The average air cadmium concentrations in these categories were 50,150 , and $500 \mu \mathrm{g} / \mathrm{m}^{3}$. Individual cumulative exposure estimates were computed by multiplying the air concentrations by the number of years spent at each exposure level.

Most of the workers $(\mathrm{N}=60)$ participated in a thorough health examination in 1983 (18-20). In 1989, 16 workers with pronounced tubular dysfunction in 1984 took part in a follow-up examination (21). The original 60 workers were invited in 1993 to a comprehensive examination of their renal function, including measurements of urinary proteins and the determination of the glomerular filtration rate (3). Six of the initially invited workers were deceased, 2 were more than 80 years old and excluded for practical reasons, and 6 refused to participate. Finally, 46 persons took part in the present investigation, and more details are given in previous reports $(3,18,19)$.

Morning urine samples were collected in polyethylene bottles. In order to prevent degradation of $\beta_{2}$-microglobulin due to acidic urine $(\mathrm{pH}<5.6)$ each subject was instructed to ingest $4 \mathrm{~g}$ of sodium bicarbonate (Samarin $\left.^{(}\right)$the night before the sampling. $\beta_{2}$-Microglobulin in urine was measured by a radio immunoassay method (Phadebas kit, Pharmacia, Sweden). Protein HC ( $\alpha_{1}$-microglobulin) was measured by a zone immunoelectrophoresis assay (14). The U-NAG was measured using a fluorometric method (22). The U-Cd and B-Cd were measured by atomic absorption spectrophotometry (23). The cadmium analyses were carried out at the Department of Occupational and Environmental Medicine in Linköping, which participates in external quality control exercises and is approved by the Swedish Board of Occupational Safety and Health. B-Cd was not measured in 1984 (due to a shortage of funding).

All the urinary measures were adjusted to creatinine. This procedure was crucial as the urine concentrations were used for the assessment of both dose and effect (eg, correlating U-Cd to U-NAG) (11).

For U- $\beta_{2}-$ microglobulin, the 95 th percentile $(34 \mu \mathrm{g} /$ mmol creatinine) in a standard reference population was used as the cut-off level for tubular proteinuria (24). For $\mathrm{NAG}$, it has been suggested that $2.7 \mathrm{U} / \mathrm{g}$ creatinine ( $0.31 \mathrm{U} / \mathrm{mmol}$ creatinine) (25) or $3.6 \mathrm{U} / 24 \mathrm{~h}$ (approximately $0.3 \mathrm{U} / \mathrm{mmol}$ creatinine) (26) should be used as the cut-off point. Other authors have proposed $4.0 \mathrm{U} / \mathrm{g}$ creatinine $(0.45 \mathrm{U} / \mathrm{mmol}$ creatinine) (27). In this study, $0.5 \mathrm{U} / \mathrm{mmol}$ creatinine was chosen as the cut-off limit for tubular dysfunction. No published reference material is available for protein $\mathrm{HC}\left(\alpha_{1}\right.$-microglobulin). In an unpublished study from the south of Sweden, the 95th percentile for a healthy working population was $1.0 \mathrm{mg} /$ mmol creatinine (A Grubb, personal communication). This level was thus chosen as the cut-off point.

\section{Statistical methods}

The data were analyzed using linear and logistic single and multiple regression models. Dependent variables that displayed a skewed distribution $\left(\beta_{2}\right.$-microglobulin, protein $\mathrm{HC}$ and $\mathrm{U}-\mathrm{NAG}$ ) were logarithmically transformed whenever appropriate before the regression analysis. Age-adjusted dose-response curves were computed using the group mean age ( 55 years) as the standard. The statistical packages StatView ${ }^{\mathbb{1}} 4.02$ and JMP ${ }^{\circledR} 3.1$ for Macintosh, as well as Statistica ${ }^{(1)}$ for Windows, were used for the statistical analyses.

\section{Results}

A comparison between the individual urinary excretions of $\beta_{2}$-microglobulin in 1984 and 1993 is shown in figure 1 . It is evident that the $\beta_{2}$-microglobulinuria is irreversible in most cases.

Significant associations were found between the cumulative air cadmium levels and all the parameters used to indicate tubulat proteinuria $\left[\mathrm{U}-\beta_{2}-\right.$ microglobulin, protein $\mathrm{HC}\left(\mathrm{U}-\alpha_{1}-\right.$ microglobulin $)$ and U-NAG]. Similarly, significant associations were found when current $\mathrm{U}$-Cd or current B-Cd were used as dose estimates. The strongest dose-response relationships were found when the current B-Cd level was used as the dose variable.

In table 1 the prevalence of elevated excretion of the three tubular markers in $4 \mathrm{~B}$-Cd dose categories is presented. Figure 2 shows the corresponding dose-response curves for $U-\beta_{2}$ and $U-\alpha_{1}$ (adjusted to age, ie, 55 years). The regression coefficient for B-Cd changed only marginally when a smoking habit variable was added to the model.

Table 2 shows the relations between $\mathrm{U}-\mathrm{Cd}$ and the 3 tubular markers. Age-adjusted (age 55 years) dose- 


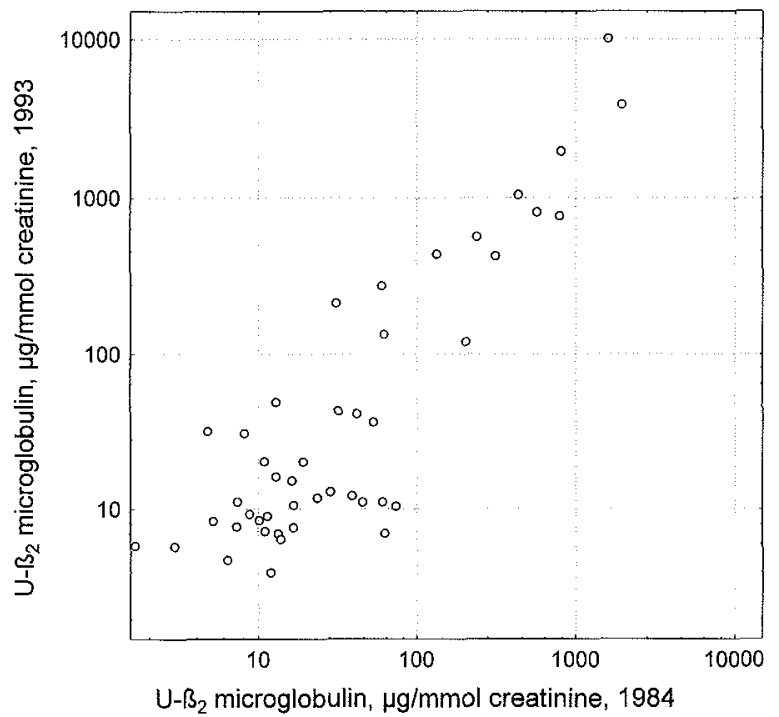

Figure 1. Comparison between the excess urinary excretion of $\beta_{2}$-microglobulin (> $34 \mu \mathrm{g} / \mathrm{mmol}$ creatinine) in 1983 and 1993 among 46 solderers highly exposed to cadmium before 1978.

Table 1. Prevalence of elevated urinary excretion of $\beta_{2}-$ microglobulin, protein $\mathrm{HC}\left(\alpha_{i}\right.$-microglobulin) and $\mathrm{N}$-Acetyl$\beta$-glucosaminidase (NAG) in relation to current (1993) blood-cadmium (B-Cd) levels.

\begin{tabular}{|c|c|c|c|c|}
\hline $\begin{array}{l}\text { B-Cd } \\
(\mathrm{nmol} / /)\end{array}$ & $\begin{array}{c}\text { Total } \\
\text { number of } \\
\text { workers }\end{array}$ & $\begin{array}{c}\beta_{2} \text { microglobulin } \\
>34 \mu \mathrm{g} / \mathrm{mmol} \\
\text { creatinine } \\
(\%)\end{array}$ & $\begin{array}{c}\text { Protein HC } \\
>1 \mathrm{mg} / \mathrm{mmol} \\
\text { creatinine } \\
(\%)\end{array}$ & $\begin{array}{c}\text { NAG } \\
>0.5 \mathrm{U} / \mathrm{mmol} \\
\text { creatinine } \\
(\%)\end{array}$ \\
\hline $\begin{array}{l}<20 \\
20<40 \\
40<60 \\
\geq 60\end{array}$ & $\begin{array}{r}11 \\
17 \\
10 \\
8\end{array}$ & $\begin{array}{c}0 \\
17.6 \\
70.0 \\
87.5\end{array}$ & $\begin{array}{r}9.1 \\
23.5 \\
90.0 \\
100\end{array}$ & $\begin{array}{r}9.1 \\
17.6 \\
30.0 \\
57.0\end{array}$ \\
\hline
\end{tabular}

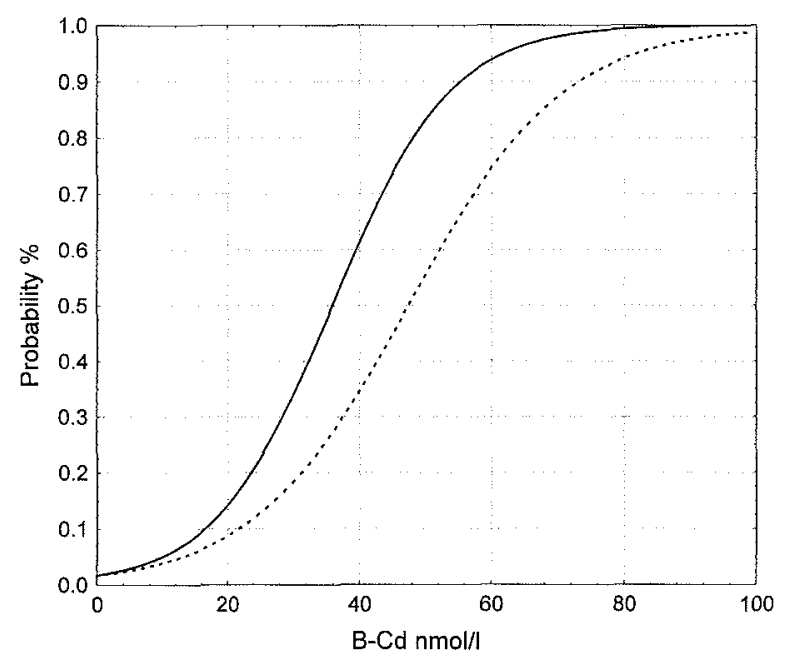

Figure 2. Probability of elevated $\beta_{2}$-microglobulin in urine $(>34 \mathrm{mg} /$ mmol creatinine, broken line) and protein $\mathrm{HC}(>1 \mu \mathrm{g} / \mathrm{mmol}$ creatinine, solid line) in relation to current blood cadmium levels (adjusted to age of 55 years).
Table 2. Prevalence of elevated urinary excretion of $\beta_{2}$ microglobulin, protein $\mathrm{HC}\left(\alpha_{1}\right.$-microglobulin) and N-Acetyl- $\beta$ glucosaminidase (NAG) in relation to current (1993) urinary cadmium (U-Cd) levels.

\begin{tabular}{lcccc}
\hline $\begin{array}{l}U-\mathrm{Cd} \\
\text { (nmol/mmol) } \\
\text { creatinine) }\end{array}$ & $\begin{array}{c}\text { Total number } \\
\text { of workers }\end{array}$ & $\begin{array}{c}\mathrm{U}-\beta_{2} \\
34 \mu \mathrm{g} / \mathrm{mmol} \\
\text { creatinine } \\
(\%)\end{array}$ & $\begin{array}{c}\text { Protein } \mathrm{HC} \\
>1 \mathrm{mg} / \mathrm{mmol} \\
\text { creatinine } \\
(\%)\end{array}$ & $\begin{array}{c}\mathrm{NAG} \\
>0.5 \mathrm{U} / \mathrm{mmol} \\
\text { creatinine } \\
(\%)\end{array}$ \\
\hline$<1$ & 6 & 0 & 16.6 & 0 \\
$1-<3$ & 14 & 0 & 0 & 0 \\
$3-<5$ & 16 & 62.5 & 62.5 & 13.3 \\
$\geq 5$ & 10 & 90.0 & 100 & 70.0
\end{tabular}

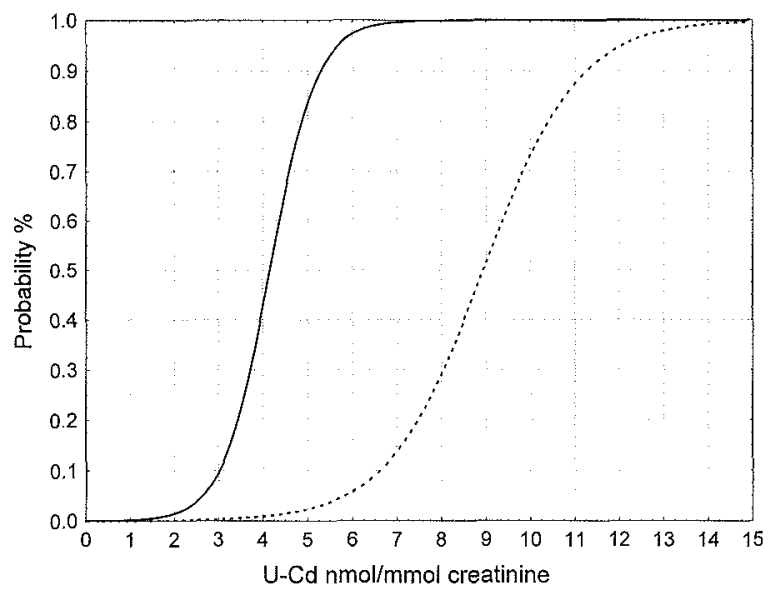

Figure 3. Probability of elevated $\beta_{2}$-microglobulin in urine $(>34 \mu \mathrm{g} /$ mmol creatinine) in relation to current (1993, solid line) and past (1984, broken line) urinary cadmium (U-Cd) levels (adjusted to age of 55 years).

response curves for $\mathrm{U}-\beta_{2}$-microglobulin are shown in figure 3 in relation to past (1984) and current (1993) U-Cd.

The U-Cd excretions in 1993 are presented in figure 4 in relation to those in 1984. Different symbols are used for persons with normal $(<0.1 \%)$, slight $(0.1 \%$ $<2.5 \%)$ and highly $(\geq 2.5 \%)$ decreased tubular reabsorption of $\beta_{2}$-microglobulin. The group mean U-Cd was much lower in $1993(3.7 \mathrm{nmol} / \mathrm{mmol}$ creatinine $)$ than in $1984(8.6 \mathrm{nmol} / \mathrm{mmol}$ creatinine)(decrease of $57 \%$ ). Among the subjects with a normal tubular function the urinary excretion had decreased from 4.2 to $2.2 \mathrm{nmol} /$ mmol creatinine $(48 \%)$, on the average, whereas for those with slight or pronounced tubular dysfunction the mean decrease was from 9.1 to $4.0(56 \%)$ and from 18.5 to $7.1 \mathrm{nmol} / \mathrm{mmol}$ creatinine $(62 \%)$, respectively. On the basis of these data the biological half-times for $\mathrm{U}-\mathrm{Cd}$ were graphically estimated to be $9.5,8.0$ and 7.2 years, respectively.

There was a good correlation $\left(\mathrm{r}^{2}=0.63, \mathrm{P}<0.0001\right)$ between $\mathrm{B}-\mathrm{Cd}$ and $\mathrm{U}-\mathrm{Cd}$, as shown in figure 5 . The two outliers had marked proteinuria $\left(\beta_{2}\right.$-microglobulin 1975 $\mu \mathrm{g} / \mathrm{mol}$ creatinine for one and $10090 \mu \mathrm{g} / \mathrm{mmol}$ creatinine for the other). 


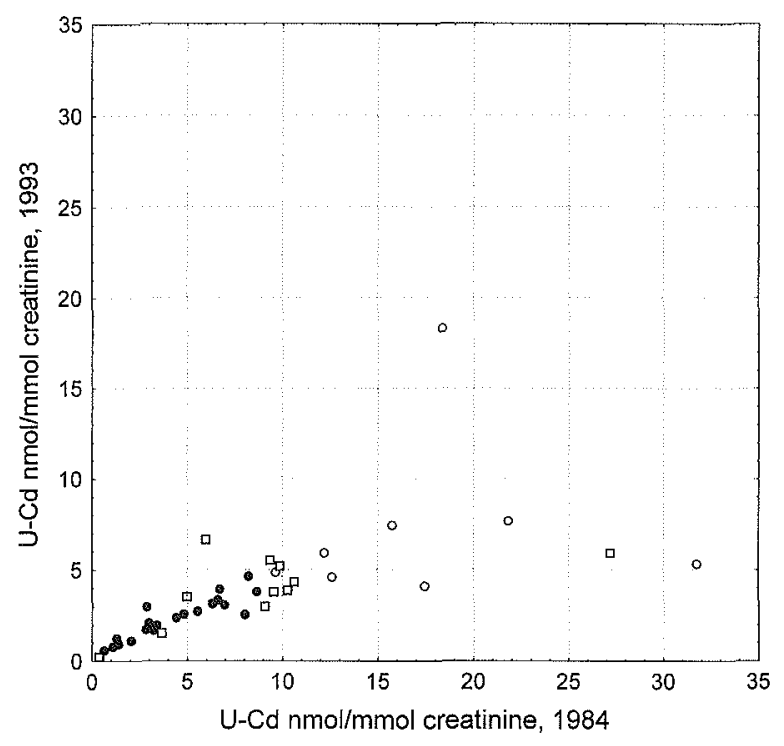

Figure 4. Comparison between the urinary excretion of cadmium (U-Cd) in 1984 and 1993. Different symbols have been used for the men with normal $\left(\beta_{2}\right.$-microglobulin clearance $<0.1$, filled circles) tubular function and those with slightly $\left(0.1<\beta_{2}\right.$-microglobulin clearance $<2.5$, unfilled squares) and highly ( $\beta_{2}$-microglobulin clearance $\geq 2.5$, unfilled circles) decreased tubular function.

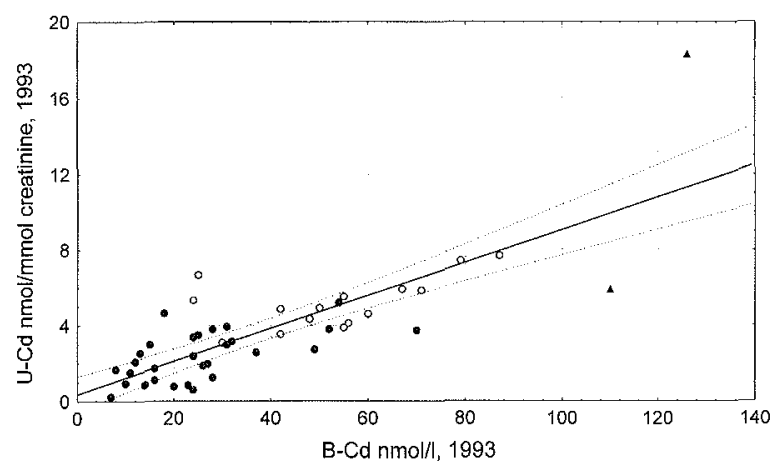

Figure 5. Comparison between cadmium in blood (B-Cd) and urine $(U-C d)$ in 1993. Different symbols have been used for the men with normal tubular function (filled circles) and tubular dysfunction ( $\beta_{2}$-microglobulin $>34 \mu \mathrm{g} / \mathrm{mmol}$ creatinine, unfilled circles). The two outliers (filled triangles) represent workers with marked tubular proteinuria $\left(\beta_{2}\right.$-microglobulin $>34 \mu \mathrm{g} / \mathrm{mmol}$ creatinine $)$.

Table 3. Occurrence of renal stones in 46 cadmium-exposed solderers in relation to current (1993) levels of cadmium in blood (B-Cd).

\begin{tabular}{lccc}
\hline $\begin{array}{l}\mathrm{B}-\mathrm{Cd} \\
(\mathrm{nmol} / \mathrm{l})\end{array}$ & $\begin{array}{c}\text { Number of subjects } \\
\text { with renal stones }\end{array}$ & $\begin{array}{c}\text { Total number of } \\
\text { subjects }\end{array}$ & $\begin{array}{c}\text { Prevalence of renal } \\
\text { stones } \\
(\%)\end{array}$ \\
\hline$<30$ & 2 & 23 & 9 \\
$\geq 30$ & 8 & 23 & 35 \\
\hline
\end{tabular}

Ten men reported a history of renal stones confirmed in medical records. The prevalence of renal stone history in 2 dose categories are shown in table 3 . The difference in prevalence between the two groups was statistically significant $(\mathrm{P}=0.04)$.

\section{Discussion}

Our most interesting finding is that $\mathrm{B}-\mathrm{Cd}$ is a useful indicator of dose. The main arguments against the use of $\mathrm{B}-\mathrm{Cd}$ for dose assessment have been that $\mathrm{B}-\mathrm{Cd}$ is markedly influenced by recent exposure and by smoking. Very high B-Cd levels are frequently seen already a few weeks after the start of exposure $(7,10,28)$. In case of a short exposure period, a relatively small amount of cadmium accumulates in the kidneys, and no signs of toxicity develop. When exposure stops B-Cd decreases relatively fast with a half-time of about 3 to 4 months (29). If exposure continues, which is typical in occupational settings, the B-Cd remains relatively stable, but the $\mathrm{U}-\mathrm{Cd}$ increases slowly because of the increasing body and kidney burden $(30,31)$. A cumulative estimate of $\mathrm{B}-\mathrm{Cd}$ dose, based on the average annual $\mathrm{B}-\mathrm{Cd}$ level during the exposure period, has been shown to be useful. On the basis of data from the regular monitoring of $\mathrm{B}-\mathrm{Cd}$ in a cadmium battery plant, it was estimated that an average $\mathrm{B}-\mathrm{Cd}$ level of $89 \mathrm{nmol} / \mathrm{l}(10 \mu \mathrm{g} / \mathrm{l})$ would result in a $14 \%$ prevalence of $\beta_{2}$-microglobulinuria after 20 years of exposure (6).

One compartment of $\mathrm{B}-\mathrm{Cd}$ is related to the body burden of cadmium $(10,29)$. If exposure to cadmium ceases, cadmium will remain elevated in blood for many years. The long-term half-time of $\mathrm{B}-\mathrm{Cd}$ is similar to that of the kidneys or the total body burden, and several years after cessation of exposure B-Cd thus reflects the body burden $(28,29)$. The dose-response curves (figure 2 and table 1) were highly significant when current B-Cd was used as the dose estimate.

However, in most other studies, U-Cd has been used as an estimate of the individual biological dose $(4,7,8$, $9,17,32)$, the major reason being the close relation between the cadmium concentration in the urine and the kidney $(2,10)$. Initially cadmium-induced kidney damage causes an increased urinary excretion of cadmium, but after some time the urinary excretion of cadmium then decreases due to losses of cadmium from the kidneys $(2,10)$. In the case of concomitant tubular damage the use of U-Cd as a dose estimate may thus be troublesome $(31,33)$. Our reexamination of previously exposed solderers showed that the U-Cd had decreased after 10 years considerably more (62\%) among the subjects with pronounced tubular damage than among those with normal tubular function ( $48 \%$ ).

U-Cd was thus a less useful indicator of dose in this long-term follow-up. The dose-response relation using U-Cd as a dose estimate (table 2, figure 3) was less 
evident than that for $\mathrm{B}-\mathrm{Cd}$. One major reason was the increased excretion of U-Cd that takes place in persons with cadmium-induced tubular damage (2). It should be noted, however, that, in almost all of the workers, the tubular damage had occurred before 1984 (when the initial investigation was made). Figure 3 illustrates some of the problems using $\mathrm{U}-\mathrm{Cd}$ as a dose estimate. In the recent (1993) follow-up, more than 10 years had elapsed since the kidney damage developed. Since then the prevalence of $\beta_{2}$-microglobulinuria has remained unchanged, whereas the U-Cd levels have decreased by about $50 \%$ (figure 4). Consequently the dose-response curve from 1993 appeared to be moved to the left, when compared with the one based on data from 1984. The most appropriate would have been to measure $\mathrm{U}-\mathrm{Cd}$ at the time when the tubular dysfunction first occurred. Such measurements were, however, not taken, and are, unfortunately, rarely feasible.

It is evident from figure 3 that dose-response data from long-term follow-up studies cannot readily be applied to populations with recent or on-going cadmium exposure. This is also true for dose-response curves based on B-Cd measured a long time after the cessation of exposure, as in figure 2.

In a previous study we found a $10 \%$ prevalence of tubular proteinuria at a U-Cd level as low as $1.5 \mathrm{nmol} /$ mmol creatinine in older workers (mean age 68.4 years), whereas this response level was reached at $5 \mathrm{nmol} / \mathrm{mmol}$ creatinine in younger workers (mean age 44.6 years) (9). In our present study, the corresponding age-adjusted prevalence of $10 \%$ was found at U-Cd levels of 2.6 and $3.5 \mathrm{nmol} / \mathrm{mmol}$ creatinine, respectively, which is well in agreement with the former results.

An increased occurrence of elevated protein $\mathrm{HC}\left(\alpha_{1}-\right.$ microglobulin) appears to be the earliest and most rapidly increasing marker of tubular dysfunction. Moreover, protein $\mathrm{HC}\left(\alpha_{1}\right.$-microglobulin) appears to be a more sensitive indicator of cadmium-induced renal damage than $\beta_{2}$-microglobulin (figure 2 and table 1 ). Protein $\mathrm{HC}$ $\left(\alpha_{1}\right.$-microglobulin), in contrast to $\beta_{2}$-microglobulin, is stable at a low $\mathrm{pH}$ in urine and is nowadays easy to analyze $(13,34)$. A disadvantage, however, is the lack of established reference data for protein $\mathrm{HC}\left(\alpha_{1}-\mathrm{mi}-\right.$ croglobulin). Nevertheless, protein HC ( $\alpha_{1}$-microglobulin) seems to be preferable to $\beta_{2}$-microglobulin for the assessment of early tubular dysfunction.

The dose-response curve for NAG was shallower, with less evidence of a threshold. This phenomenon has also been observed by Bernard et al (35), who determined the activity of 2 isoenzymes of NAG (NAG-A and NAG-B) in 56 cadmium-exposed workers and 20 referents. NAG-B correlated well with U-Cd and showed a linear increase even in the range of 0.1 to $2 \mathrm{nmol} / \mathrm{mmol}$ creatinine, which is the usual range of U-Cd for persons not occupationally exposed to cadmium. The authors suggested that the correlation between cadmium and NAG-B in urine is possibly indicative of parallel excretion rather than a sign of tubular dysfunction. Tubular apoptotic cell death could possibly produce a simultaneous loss of intracellular cadmium and NAG to the urine.

The increased risk of renal stones among men with elevated B-Cd levels agrees with previous observations from cadmium-exposed men in Sweden (36) and emphasizes the clinical relevance of tubular dysfunction. In addition several of the men had a decreased glomerular filtration rate (3).

\section{Concluding remarks}

This study shows that B-Cd is a useful indicator of dose several years after exposure has ceased. Furthermore, protein $\mathrm{HC}\left(\alpha_{1}\right.$-microglobulin) was found to be the most sensitive and earliest indicator of cadmium-induced tubular damage.

\section{Acknowledgments}

The study was carried out with funding from the Swedish Work Environment Fund.

We would like to thank Ms Sylwia Flato for performing the NAG analyses.

\section{References}

1. World Health Organization (WHO). International programme on chemical safety. Cadmium. Geneva: WHO, 1992. Environmental health criteria, 134.

2. Friberg L, Elinder CG, Kjellström T, Nordberg GF. Cadmium and health; a toxicological and epidemiological appraisal. Boca Raton (FL): CRC Press, 1986:2.

3. Järup L, Persson B, Elinder CG. Decreased glomerular filtration rate in cadmium exposed solderers. Occup Environ Med $1995 ; 52: 818-22$.

4. Kjellström T, Evrin PE, Rahnster B. Dose-response analysis of cadmium-induced tubular proteinuria: a study of urinary beta $_{2}$-microglobulin excretion among workers in a battery factory. Environ Res 1977;13:303 - 17.

5. Bernard AM, Buchet JP, Roels H, Masson P, Lauwerys R. Renal excretion of proteins and enzymes in workers exposed to cadmium. Eur J Clin Invest 1979;9:11-22.

6. Järup L, Elinder CG, Spång G. Cumulative blood-cadmium and tubular proteinuria - a dose-response relationship. Int Arch Occup Environ Health 1988;20:114-7.

7. Lauwerys R, Roels H, Bernard A, Buchet JP. Significance of cadmium concentration in blood and urine in workers exposed to cadmium. Environ Res 1979;20:375-91.

8. Nogawa $K$, Kobayashi E, Honda R. A study of the relationship between cadmium concentrations in urine and renal effects of cadmium. Environ Health Perspect 1979;28:161-8.

9. Järup L, Elinder CG. Dose-response relations between urinary cadmium and tubular proteinuria in cadmium exposed work- 
ers. Am J Ind Med 1994 26:759-69.

10. Friberg L, Elinder CG, Kjellström T, Nordberg GF. Cadmium and health: a toxicological and epidemiological appraisal. Boca Raton (FL): CRC Press, 1985:1.

11. Elinder CG, Gerhardsson L, Oberdörster G. Biological monitoring of toxic metals - overview. In: Clarkson TW, Friberg L, Nordberg GF, Sager PR, editors. Biological monitoring of toxic metals. New York and London: Plenum Press, 1988:1 71.

12. Bernard AM, Moreau D, Lauwerys R. Comparison of retinol binding protein and $\beta$, -microglobulin determination urine for the early detection of tubular proteinuria. Clin Chim Acta 1982;126:1-9.

13. Grubb A. Diagnostic value of analysis of cystatin $\mathrm{C}$ and protein HC in biological fluids. Clin Nephrol 1992;38 suppl: S20-S27,

14. Holmqvist L, Vesterberg O, Persson B. Apolipoprotein D and alpha-1-microglobulin in human urine: effect of cadmium exposure. Int Arch Occup Environ Health 1993;64:469-72.

15. Weber MH. Diagnosis of tubular proteinuria. Clin Diagn Lab Med 1988:2:56-65.

16. World Health Organization (WHO). Principles and methods for the assessment of nephrotoxicity associated with exposure to chemicals. Geneva: WHO, 1991. Environmental health criteria, 119.

17. Roels H, Bernard AM, Cardenas A, Buchet JP, Lauwerys R, Hotter $G$, et al. Markers of early renal changes induced by industrial pollutants, III: application to workers exposed to cadmium. Br J Ind Med 1993;50:37—8.

18. Elinder CG, Edling C, Lindberg E, Kågedal B, Vesterberg O. $\beta_{2}$ microglobulinuria among workers previously exposed to cadmium: follow-up and dose-response analyses. Am J Ind Med 1985;8:553-64

19. Elinder CG, Edling C, Lindberg E, Kågedal B, Vesterberg O. Assement of renal function among workers previously exposed to cadmium. Br J Ind Med 1985;42:754 -60.

20. Edling C, Elinder CG, Randma E. Lung function in workers using cadmium containing solders. Br J Ind Med 1986;43: $657-62$.

21. Järup L, Persson B, Edling C, Elinder CG. Renal impairment in workers previously exposed to cadmium. Nephron 1993;64: $75-81$.

22. Yuen CT, Price RG, Chattagoon L, Richardson AC, Praill PF. Colorimetric assays for $\mathrm{N}$-acetyl-beta-D-glucosaminidase and beta-D-galactosidase in human urine using newly-developed omega-nitrostyryl substrates. Clin Chim Acta 1982;124:195204.

23. Lagesson V, Andrasko L. Direct determination of lead and cadmium in blood and urine by flameless atomic absorption spectrophotometry. Clin Chem 1979;25:1948 - 53.

24. Kowal NE, Zirkes M. Urinary cadmium and beta ${ }_{2}$-microglobulin: normal values and concentration adjustment. J Toxicol Environ Health 1983;11:607-24,

25. Bernard AM, Roels H, Cardenas A, Lauwerys R. Assessment of urinary protein 1 and transferrin as early markers of cadmium nephrotoxicity. Br J Ind Med 1990;47:559—65.

26. Buchet JP, Lauwerys R, Roels H, Bernard A, Bruaux P, Claeys $\mathrm{F}$, et al. Renal effects of cadmium body burden of the general population. Lancet 1990;336:699-702. Published erratum appears in Lancet 1991:22;337(8756):1554.

27. Klein G. Ergebnisse der multizentrischen Ermittlung vorläufiger Referenzbereiche für beta-N-Acetylglucosaminidase im Urin von Erwachsenen. [Results of multicenter determination of preliminary reference values for beta- $\mathrm{N}$-acetylglucosaminidase in urine of adults]. Wien Klin Wochenschr [suppl] 1991;189:50—1.

28. Kjellström T, Nordberg GF. A kinetic model of cadmium metabolism in the human being. Environ Res 1978;16:24869.

29. Järup L, Rogenfelt A, Elinder C-G, Nogawa K, Kjellström T. Biological half-time of cadmium in the blood of workers after cessation of exposure. Scand J Work Environ Health 1983;9: 327-31.

30. Nordberg G, Nordberg M. Biological monitoring of cadmium. In: Clarkson TW, Friberg L, Nordberg GF, Sager PR editors. Biological monitoring of toxic metals. New York and London: Plenum Press, 1988:151 -68

31. Elinder CG. Biological monitoring of cadmium. In: Dillon HK, Ho MH editors. Biological monitoring of exposure to chemicals: metals. New York (NY): John Wiley \& Sons Inc, 1991:197-207.

32. Chia KS, Ong CN, Ong HY, Endo G. Renal tubular function of workers exposed to low levels of cadmium. Br J Ind Med 1989:46:165-70.

33. Elinder CG, Friberg L, Nordberg GF, Kjellström T, Oberdoerster G. Biological monitoring of metals: chemical safety monographs. Geneva: WHO, 1994:1-80.

34. Yu H, Yanagisawa Y, Forbes MA, Copper E, Crockson RA, MacLennan I CM. Alpha-1-microglobulin: an indicator protein for renal tubular function. J Clin Pathol 1983;36:253-9

35. Bernard A, Thielemans N, Roels H, Lauwerys R. Association between NAG-B and cadmium in urine with no evidence of a threshold. Occup Environ Med 1995;52:177—180.

36. Järup L, Elinder CG. Renal stone incidence among cadmium exposed battery workers. Br J Ind Med 1993;50:598-602.

Received for publication: 2 February 1996 